J. Environ. Sci.

Institute of Environmental Studies and Research - Ain Shams University

\title{
ASSESSING NUCLEIC ACID TESTING VERSUS ELIZA FOR BLOOD VIRUSES DETECTION IN SOME BLOOD BANKS
}

\author{
Nanis S. A. El Attar ${ }^{(1)}$; Mostafa H. Ragab ${ }^{(1)}$ \\ and Magda E. M. El Mahdy ${ }^{(2)}$
}

1) Department of Environmental Medical sciences, Institute of Environmental Studies and Researches, Ain Shams University 2) Department of Clinical Pathology, Al-Azhar University

\begin{abstract}
INTRODUCTION: The goal of any transfusion service is to provide adequate and safe blood and blood products that meet the needs of patients. Transfusion-transmissible viral infections, such as hepatitis $\mathrm{C}$ virus (HCV), hepatitis B virus (HBV), and human immunodeficiency virus (HIV), remain a major public health problem in developing countries. Nucleic acid testing (NAT) is a molecular technique for screening blood donations to reduce the risk of transfusion transmitted infections (TTIs) in the recipients, thus providing an additional layer of blood safety.

AIM OF THE WORK: To assess the importance of implementing NAT assay to detect donors during window period which are not detected with Enzyme-linked immunoassay (ELISA).

SUBJECTS AND METHODS: This cross sectional study was conducted at the Egyptian Abbassia regional Blood Transfusion center (ARBTC) at Abbassia, Cairo. Blood donation collected from 10000 voluntary donors from January 2016 to June 2016 and tested with both ID NAT and ELISA assays for HBV, HCV and HIV.

RESULTS: NAT testing has the potential to detect viral nucleic acids of HIV 1-2, HBV, and HCV earlier than current screening methods.

CONCLUSION: The implementation of NAT screening for three viruses has improved blood safety and reduced transfusion-transmitted infections.
\end{abstract}


KEYWORDS: Hepatitis B virus, hepatitis C virus, human immunodeficiency virus, nucleic acid amplification testing, transfusiontransmitted infection, Enzyme-linked immunosorbent assay.

\section{INTRODUCTION}

Transfusion-transmissible viral infections, such as hepatitis $\mathrm{C}$ virus (HCV), hepatitis B virus (HBV), and human immunodeficiency virus (HIV), remain a major public health problem in developing countries. The prevalence of these viral infections among blood donors may reflect the burden of these diseases among populations (Biadgo et al., 2017). The goal of any transfusion service is to provide adequate and safe blood and blood products to the recipients. With every unit of blood transfusion, there is a $1 \%$ chance of transfusion related complications including transfusion-transmitted infections. The process of preventing the TTI presents one of the greatest challenges of transfusion medicine. Blood transfusion departments not only screen TTI, but they also provide information about the prevalence of these infections in populations (Sushma et al., 2016). Availability of safe supplies of blood and blood products cannot be achieved without costs. However, an unsafe or inadequate blood supply is ultimately even more costly, in both human and economic terms (Smit, 2017). The human costs of unsafe blood are incalculable- morbidity and mortality resulting from the transfusion of infected blood have far-reaching Consequences, not only for the recipients themselves, but also their families, their communities and the wider society (Patel et al., 2012). In the last few decades through an awareness of TTIs, a majority of countries have mandated serology based blood screening assays 
for HIV, HCV, and HBV. However, despite improved serological assays, the transfusion transmission of $\mathrm{HTV}, \mathrm{HCV}$, and $\mathrm{HBV}$ continues, primarily due to release of serology negative units that are infectious because of the window period (WP) (Shyatnala, 2014). The WP is that period of time from infection to the time of detection by a given blood screening assay (Weusten et al., 2011). During this period, the risk of infection in donated blood can be missed by the immunoassay testing. These undetected WP infections are responsible for most of the transfusion transmission of these viruses (Chigurupati and Murthy, 2015). Nucleic acid amplification technology (NAT) is highly sensitive and specific for viral nucleic acids. It is based on amplification of targeted regions of viral ribonucleic acid or deoxyribonucleic acid (DNA) (Hans and Marwaha, 2014).It detects them earlier than the other screening methods thus, narrowing the window period of HIV, HBV and $\mathrm{HCV}$ infections. NAT also adds the benefit of resolving false reactive donations on serological methods which is very important for donor notification and counseling (Yaseen et al., 2013). The need for NAT depends on the prevalence and incidence rate of infections in blood donor population, available resources and the evidence of benefit added when combined with serology tests. (Hans and Marwaha, 2014).

The aim of this work is to assess the importance of implementing NAT assay to detect donors during window period (the duration between the donor exposures to a virus until antibodies against the virus are produced) which are not detected with ELISA. Also, it detects the impact of NAT on the yield and residual risk of TTIs. 


\section{SUBJECTS AND METHODS}

This cross sectional study was conducted at the Egyptian Abbassia regional Blood Transfusion center (ARBTC) at Abbasiaa, Cairo. The period of the study was six months from January 2016 to June 2016. Blood was collected from 10000 voluntary donors. They donated blood either in the blood bank or in the camps organized by mobile teams.

Inclusion criteria: the following are some of the criteria universally accepted for donor selection under universal regulation of American Association of blood banks and the instructions on work procedures produced by the general administration of blood banking of the Egyptian Ministry of Health.

- Age between 18-60 years

- Weight of the donor should be at least 50 kilos

- Haemoglobin levels of $12 \mathrm{~g} / \mathrm{dl}$ for females and $13 \mathrm{~g} / \mathrm{dl}$ for males.

- Pulse between 50 to 100 / min with no irregularities.

- Blood pressure systolic 90-180 mmHg and diastolic 60-100 mmHg.

- The minimum interval between blood donations varies between 56 days ( 8 weeks) and 16 weeks and different donation intervals are usually followed for male and female donors

- All donors must pass general and medical examinations prior to donation.

Exclusion criteria include (Donor deferral): Individuals disqualified for donating blood are known as the "deferred" donors. Person is deferred temporarily or permanently will depend on their specific reason for disqualification (e.g. a person may be deferred temporally because of anemia. A condition that is usually reversible). Criteria for rejecting donors: 
- Hypotension, hypertension, anemia and sever chronic disease

- Anyone with positive test for HIV.

- Men and women who have engaged in unprotected sex.

- Anyone who has a past history of hepatitis.

All blood donors, involved with in our research were requested to complete a detailed questionnaire and sign consent before being enrolled in this study.

1-A universally recognized and detailed questionnaire was taken during these donors registration. Information regarding risk factors as past history of surgery, prior hospitalization, history of blood transfusion and donation, occupation, high risk behavior (multi sexual partner), and history of vaccination, or any episode of jaundice was recorded.

2-Sample Collection was carried out at the beginning of phlebotomy by 1617 gauge needles, $5 \mathrm{ml}$ venous blood was drawn from donors in plain tubes (Becton Dickenson) and used to obtain serum by centrifugation. Blood donor samples were subjected to screening for HIV, hepatitis B virus (HBV) and hepatitis B virus (HCV) by using fully automated enzyme-linked immunosorbent assay (ELISA) processor of FAME, Labtop, India. The tests performed were HBV surface antigen (HBsAg) to detect $\mathrm{HBV}$, anti-HCV to detect $\mathrm{HCV}, 4^{\text {th }}$ generation ELISA kits to detect p24 antigen and glycoprotein antibodies against HIV and Individual NAT(ID NAT)Using the PROCLEIX® TIGRIS ${ }^{\circledR}$ System, ID-NAT depending on transcription mediated amplification (TMA) Technology. TMA assay involves three main steps utilizing three proprietary technologies: 
(a) Target capture based sample preparation,

(b) Transcription-mediated amplification,

(c) Hybridization protection assay.

\section{STATISTICAL METHODS}

Data were collected, processed and analyzed on PC computer. Statistic package for social science program (SPSS) were used for analysis of this data, numerical data were presented in the form of number and percentage, proper significant test were used for analysis and p-value $<0.05$ was considered statistically significant (SPSS12,2004).

\section{RESULTS}

Table (1): Incidence of blood born viruses in reactive samples by ELISA

\begin{tabular}{|c|c|c|c|c|c|c|}
\hline \multirow{2}{*}{} & \multicolumn{2}{|c|}{ Positive } & \multicolumn{2}{c|}{ Negative } & \multirow{2}{*}{$\mathbf{2}$} & P \\
\cline { 2 - 5 } & No. & \% & No. & \% & & \\
\hline \hline HCV & 464 & 4.64 & 9536 & 95.36 & & \multirow{2}{*}{0.41} \\
\hline HBV & 156 & 1.56 & 9844 & 98.44 & 0.521 \\
\hline Total number & 620 & 6.2 & 9380 & 93.80 & & \\
\hline
\end{tabular}

There was no significant difference in blood born viruses in reactive samples, were $\mathrm{P}>0.05$. 
J. Environ. Sci.

Institute of Environmental Studies and Research - Ain Shams University

Table (2): Incidence of $\mathrm{HCV}, \mathrm{HBV}$ and $\mathrm{HIV}$ reactive cases according to gender

\begin{tabular}{|c|c|c|c|c|c|c|c|c|c|c|}
\hline \multirow{3}{*}{ Gender } & \multirow{2}{*}{\multicolumn{2}{|c|}{$\begin{array}{c}\text { Total No } \\
\text { of } \\
\text { reactive } \\
\text { samples }\end{array}$}} & \multicolumn{2}{|c|}{ HCV } & \multicolumn{2}{|c|}{ HBV } & \multicolumn{2}{|c|}{ HIV } & \multicolumn{2}{|c|}{$\begin{array}{c}\text { Chi-square } \\
\text { test }\end{array}$} \\
\hline & & & \multirow[t]{2}{*}{ No. } & \multirow[t]{2}{*}{$\%$} & \multirow[t]{2}{*}{ No. } & \multirow[t]{2}{*}{$\%$} & \multirow[t]{2}{*}{ No. } & \multirow[t]{2}{*}{$\%$} & \multirow{2}{*}{$\chi^{2}$} & \multirow{2}{*}{$\begin{array}{c}\text { p- } \\
\text { value }\end{array}$} \\
\hline & No. & $\%$ & & & & & & & & \\
\hline Male & 542 & 5.42 & 404 & $4.04 \%$ & 138 & $1.38 \%$ & 0 & $0 \%$ & \multirow{3}{*}{0.290} & \multirow{3}{*}{0.587} \\
\hline Female & 78 & 0.78 & 60 & $0.60 \%$ & 18 & $0.18 \%$ & 0 & $0 \%$ & & \\
\hline Total & 620 & 6.20 & 464 & $4.64 \%$ & 156 & $1.56 \%$ & 0 & $0 \%$ & & \\
\hline
\end{tabular}

There was no significant difference in viral infections distribution between male and female.

The percentage of reactive male donor were $542(5.42 \%)$ and that of females donors were $78(0.78 \%)$ of total tested samples

Table (3): Incidence of $\mathrm{HCV}, \mathrm{HBV}$ and $\mathrm{HIV}$ reactive cases according to age group

\begin{tabular}{|c|c|c|c|c|c|c|c|}
\hline \multirow{2}{*}{$\begin{array}{c}\text { Age } \\
\text { (years) }\end{array}$} & \multirow{2}{*}{$\begin{array}{c}\text { Total No. of } \\
\text { reactive } \\
\text { samples }\end{array}$} & \multicolumn{2}{|c|}{ HCV } & \multicolumn{2}{|c|}{ HBV } & \multirow{2}{*}{ x2 } & \multirow{2}{*}{ p-value } \\
\cline { 3 - 6 } & & No. & No. & $\%$ & & \\
\hline \hline$<20$ & 11 & 9 & $0.09 \%$ & 2 & $0.02 \%$ & & \\
\hline $20-<30$ & 323 & 204 & $2.04 \%$ & 119 & $1.19 \%$ & & \\
\hline $30-<40$ & 178 & 169 & $1.69 \%$ & 9 & $0.09 \%$ & \multirow{2}{*}{63.605} & $<0.001 * *$ \\
\hline $40-<50$ & 81 & 59 & $0.59 \%$ & 22 & $0.22 \%$ & & \\
\hline $50-<60$ & 27 & 23 & $0.23 \%$ & 4 & $0.04 \%$ & & \\
\hline Total & 620 & 464 & $4.64 \%$ & 156 & $1.56 \%$ & & \\
\hline
\end{tabular}

There was highly statistically significant difference in viral infections distribution between age group. 
Table (4): NAT discriminatory results

\begin{tabular}{|c|c|c|}
\hline Parameters & No of samples & $\begin{array}{c}\text { Percentage\% to total } \\
\text { tested samples }\end{array}$ \\
\hline HBV & 3 & $0.003 \%$ \\
\hline HCV & 4 & $0.004 \%$ \\
\hline Total NAT yield samples & 7 & $0.007 \%$ \\
\hline
\end{tabular}

The fact that single donation is used for generating 3 components, The

NAT yield becomes 3 times that is, 21 blood products

Table (5): Incidence of HBV, HCV and HIV false reactive results (reactive

ELISA and negative NAT)

\begin{tabular}{|c|c|c|c|c|}
\hline Parameters & $\begin{array}{c}\text { No of } \\
\text { samples }\end{array}$ & $\begin{array}{c}\text { Percentage\% to total } \\
\text { tested samples }\end{array}$ & $\mathbf{x} 2$ & p-value \\
\hline HBV & 29 & $0.29 \%$ & \multirow{4}{*}{60.37} & \multirow{4}{*}{$<0.001 * *$} \\
\hline $\mathrm{HCV}$ & 76 & $0.76 \%$ & & \\
\hline HIV & 18 & $0.18 \%$ & & \\
\hline Total & 123 & $1.23 \%$ & & \\
\hline
\end{tabular}

There was significant difference were $\mathrm{p}<0.001$

\section{DISCUSSION}

Blood transfusion saves millions of lives worldwide each year. However, transfusion-transmissible infections (TTIs) are a major problem associated with blood transfusion, particularly in developing countries. The magnitude of this problem is directly related to the prevalence of TTIs among blood donors. Each blood transfusion carries a risk of transmitting blood-borne pathogens (Biadgo et al., 2017). The safety of blood and blood components continues to raise debate all over the world. In the past few decades, many measures have been introduced in order to reduce the risk of transmission of blood-borne viruses. Blood safety has been achieved through many factors 
including more stringent donor selection criteria, improved sensitivity of the screening tests, and inclusion of NAT testing in the routine screening program (Stanic et al., 2017). This current study shows the value of NAT in blood screening, NAT have the potential to detect viral nucleic acids of HIV 1-2, HBV, and HCV earlier than current screening methods, also to focus on the primary benefit of NAT in reducing residual risk of infectious window period donations, identify NAT yield and save donations from being wasted due to their false reactivity by ELISA testing. The prevalence of transfusion transmitted viruses among the 10000 studied donors were $4.64 \%$ for $\mathrm{HCV}$ and $1.56 \%$ for $\mathrm{HBV}$, that agrees with a pervious study done on voluntary non remunerated donors in National Blood Transfusion Center (NBTC), the prevalence of $\mathrm{HCV}$ and $\mathrm{HBV}$ were $4.8 \%$ and $1.5 \%$ respectively (Ashour et al., 2009). These rates can be compared with a study from Pakistan the prevalence of Hepatitis B, Hepatitis C, was found to be 1.84, 1.7, \% respectively (Arshad et al., 2016). On the contrary to current study, A study done at Beniseuf University hospital on 30055 blood samples collected from November 2007 to April 2015 reported seroprevalence of anti-HCV and HBsAg of $9.4 \%$ and $1.6 \%$ respectively (Fouad et al., 2016), another study done at Suez Canal University hospital on 149,381 blood samples collected from January 1996 to December 2011 reported seroprevalence of anti-HCV and HBsAg of $7.2 \%$ and $2.3 \%$ respectively (Hesham and Atwa, 2013). The prevalence of blood-borne viruses according to gender was male blood donors $86.7 \%$ respectively and only $13.24 \%$ females were included. The high ratio of male to female blood donors in this study was agreed with studies from other countries for example, in a study from Northern Pakistan done on 
56,772 donors, Of these donors, 55,985 (98.6\%) were male and $787(1.4 \%)$ were female, with a mean age of 29 years (range, 18-60 years) (Niazi et al., 2015). Also agree with a study done in Suez Canal University Hospital Blood Bank125, 562 blood donors (84\%), were males, compared to 23,819 (16\%) females. In Egypt, most women are usually housewives and this may lead them to avoid outdoor activities. Moreover, women have lower hemoglobin levels and a higher number of vasovagal reactions. This may cause the high rate of refusal for women donors (Hesham and Atwa, 2013).

The incidence of $\mathrm{HCV}, \mathrm{HBV}$ and HIV reactive cases according to age group were the largest age group among donors in our study was between 20 to 30 years $43.2 \%$ and the majority of the reactive donors were also from the same age group i.e. 20-30 years. The sero-positive prevalence of HBsAg was 119 donors $(1.19 \%)$.However, the sero-positive prevalence of $\mathrm{HCV}$ is 204 donors $(2.04 \%)$. There was a significant association among the age of the donor and infection with hepatitis $B$ virus, hepatitis $C(p<0.001)$, this agree with a study in Sudan done on 1204 donations collected in Kosti teaching hospital. Average age of the donors was 28 years (range 18 years to 65 years). The majority of the donors were in their third decade of life. The seropositive prevalence of HBsAg was 66 donors (5.5\%). However, the seropositive prevalence of $\mathrm{HCV}$ is 41 donors (3.4\%). All donors with seropositive $\mathrm{HCV}$ were between 20 and 40 years old (3.4\%). All donors with sero-positive HBV were between 20 and 40 years old, which is comparable with our study (Bazie et al., 2015). Whereas the study done in Turkey showed decrease in the prevalence of sero-positive donors in the last years (24) and 
this due to the high health educations programs (Emekdas et al., 2006). NAT discriminatory results; in our study we identified 7 samples $(0.07 \%)$ as NAT yield (sero-negative samples and NAT reactive) of total 10000 tested samples. The NAT yield of 7 samples in 10000 samples assumes more significance when one considers the fact that single donation is used for generating 3 components (packed RBCs, plasma, platelet) that can be used by 3 recipients. Hence, in effect the NAT yield becomes 3 times that is, 21 in 10000 donations, Saving 21 recipients from TTIs less statically nonsignificant but worth to decrease rate of infection.

Our NAT yield rate was 1:2500 for HCV and1:3333 HBV for which is much higher than NAT yield rate in studies from developed countries that have already implemented NAT technology, in United States, it was seen that over a 10-year period, approximately 66 million donations were screened with NAT and the yield of HCV was 1:270,000 and for HIV 1: 2000000 (Zou et al., 2010). On other hand, in developing countries like South Africa, Thailand, Kuwait, and Malaysia the NAT yield was 1: 52303, 1: 4868, 1: 24275, and 1: 3616 donations, respectively (El Ekiaby et al., 2010).

NAT yield rate $=$ NAT yield: total tested samples (Roth et al., 2012).

The Incidence of HBV, HCV and HIV false reactive results in the current study the total number of false positive tested samples (serology reactive and NAT free samples were 123 samples (1.23\%) of total tested samples which were relatively high and this was agreed with a Malaysian study, 1388 donor samples were tested by serology as well as NAT, authors found $1.37 \%$ samples reactive on standard serology methods but non-reactive by NAT, 
these samples were confirmed to be "false reactive" on confirmatory serological tests (Yassen et al.,2013).

\section{CONCLUSION}

Finally, we concluded that with increased prevalence of TTIs and incidence of infection, we need to augment TTIs testing, implementation of more sensitive tests such as NAT testing for HIV, HBV and HCV that detect infection earlier (reduce the window period) will further decrease risks of TTIs and save donations from being wasted due to their false reactivity by ELISA testing.

\section{REFERENCES}

Arshad, A.; Borhany, M.; Anwar, N.; Naseer, I.; Ansari, R.; Boota, S.; Zaidi, M. and Shamsi, T. (2016): Prevalence of transfusion transmissible infections in blood donors of Pakistan. BMC hematology, 16(1): 27-35.

Ashour, D.; Moftah, F.; Gobran, H. and Ekram, D.(2009): Decreasing the risk of TTIs in Egyptian blood transfusion services. Vox Sang.; 6:102108.

Bazie, E. A.; Ali, M. A.; Hamza, H. B.; Magzoub, O. S.; Salih, M. S. and Haroun, B. E.(2015): Sero-prevalence of viral transfusiontransmissible infections among blood donors at Kosti Teaching Hospital, White Nile State/Sudan. Int J Curr Microbiol App Sci, 4(5): 1132-8.

Biadgo, B.; Shiferaw, E.; Woldu, B.; Alene, K. A. and Melku, M.(2017): Transfusion-transmissible viral infections among blood donors at the North Gondar district blood bank, northwest Ethiopia: A three year retrospective study. PloS one, 12(7): 1-12. 
Chigurupati, P. and Murthy, K. S:.Automated nucleic acid amplification testing in blood banks: an additional layer of blood safety. Asian journal of transfusion science, 9(1): 9-11, (2015).

El Ekiaby, M.; Lelie, N. and Allain, J.(2010): Nucleic acid testing in high prevalence-low resource settings. Biologicals, 38(1):59-64.

Fouad M.; Ismail, N. and Mahmoud, R.(2016): Sero-Prevalence of HBV, HCV, HIV, and Syphilis Among Blood Donors at Beni seuf University hospital Blood bank, Int J Clin Exp Pathol,10(3):38163821.

Gurol, E.; Saban, C.; Oral, O.; Cigdem, A. and Armagan, ATrends in hepatitis $\mathrm{B}$ and hepatitis $\mathrm{C}$ virus among blood donors over 16 years in Turkey. European journal of epidemiology, 21(4): 299305, (2006).

Hans, R. and Marwaha, N.(2014): Nucleic acid testing-benefits and constraints. Asian J Transfus Sci, 8(1):2-3.

Hesham, N. A. and Atwa, M.(2013): Seroprevalence of HBV, HCV, HIV and syphilis markers among blood donors at Suez Canal University Hospital Blood Bank. J Blood Disorders Transf, 5(1):177-183.

Niazi, S. K.; Bhatti, F. A.; Salamat, N.; Ghani, E. and Tayyab, M.(2015): Impact of nucleic acid amplification test on screening of blood donors in Northern Pakistan. Transfusion, 55(7): 1803-1811.

Patel, P. A.; Patel, S. P. and Oza, H. V.(2012): Seroprevalence of transfusion transmitted infections (TTIs) in blood donors at western Ahmed abad-A secondary care hospital based study. Int J Biol Med Res, 3(2):1806-1810.

Roth, W. K.; Busch, M. P.; Schuller, A.; Ismay, S.; Cheng, A.; Seed, C. R.; Jungbauer, C.; Minsk, P. M.; Sondag-Thull, D.; Wendel, S. and Levi, J. E.(2012): International survey on NAT testing of blood donations: expanding implementation and yield from 1999 to 2009. VoxSanguinis, 102(1): 82-90. 
Shyamala, V: Factors in enhancing blood safety by nucleic acid technology testing for human immunodeficiency virus, hepatitis $\mathrm{C}$ virus and hepatitis B virus. Asian journal of transfusion science, 8(1): 1319, (2014).

Sibinga, C. T .S.: Existing and recommended legislative framework for a National blood transfusion policy. Global Journal of Transfusion Medicine, 2(2): 89-96, (2017).

Stanic, H. S.; Babic, I.; Maslovic, M.; Dogic, V.; Bingulac-Popovic, J.; Miletic, M.; Jurakovic-Loncar, N.; Vuk, T.; Strauss-Patko, M. and Jukic, I.(2017): Three-Year Experience in NAT Screening of Blood Donors for Transfusion Transmitted Viruses in Croatia. Transfusion Medicine and Hemotherapy, 44(6): 415-420.

Smit, S. (2017): Existing and recommended legislative framework for a national blood transfusion policy. Glob J Transfus Med, 2(2):8996.

Sushma, K.; Ritesh, K. and Ramesh, K. (2016): Spectrum of Transfusion Transmitted Infections Among Apparently Healthy Blood Donors in Blood Bank RIMS Ranchi From 2008 to 2014, Open Science Journal, 1(2):1-9.

Weusten, J.; Vermeulen, M.; van Drimmelen, H. and Lelie, N. (2011): Refinement of a viral transmission risk model for blood donations in seroconversion window phase screened by nucleic acid testing in different pool sizes and repeat test algorithms. Transfusion, 51(1): 203-215.

Yaseen, S. G.; Ahmed, S. A.; Johan, M. F.; Kiron, R. and Daher, A. M. (2013): Evaluation of serological transfusion-transmitted viral diseases and mutliplex nucleic acid testing in malaysian blood donors. Transfusion and Apheresis Science, 49(3): 647-651. 
Zou, S.; Dorsey, K. A.; Notari, E .P.; Foster, G. A.; Krysztof, D. E.; Musavi, F.; Dodd, R. Y. and Stramer, S. L. (2010): Prevalence, incidence, and residual risk of human immunodeficiency virus and hepatitis $\mathrm{C}$ virus infections among United States blood donors since the introduction of nucleic acid testing. Transfusion, 50(7):14951504.

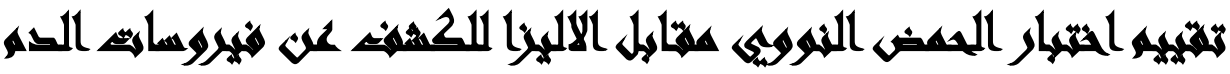

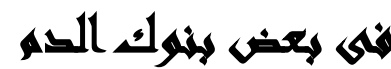

[r]

نانيس صلاح الدين عطيه (العطار (')- مصطفى حسن رجب(')- ماجدة إبراهيم محمد المهرى(ب)(

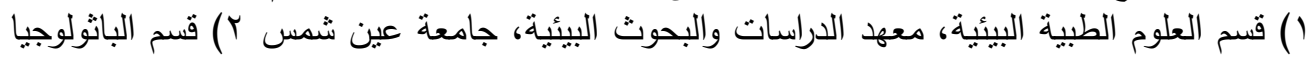

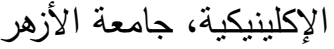

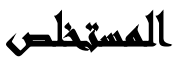

يتمثل الهوف من خدمات نقل الدم فى توفير الدم ومنتجاته بصورة مناسبة وآمنة تلبي احتباجات

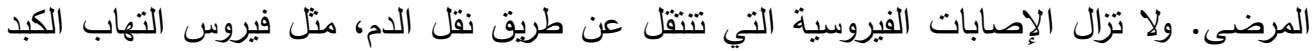

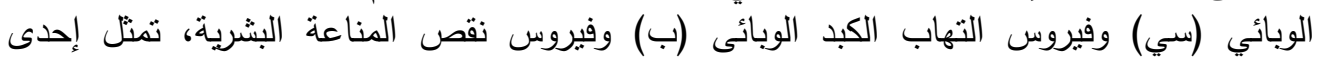

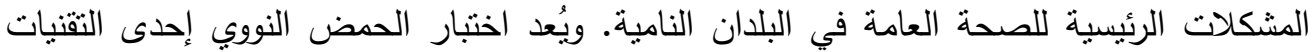
الجزيئية التى تهدف إلى فحص المتبرعين بالدم للحد من مخاطر انتقال العدوى عن طريق الدئ الدم بين

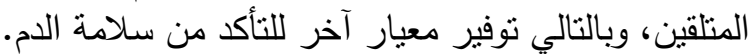

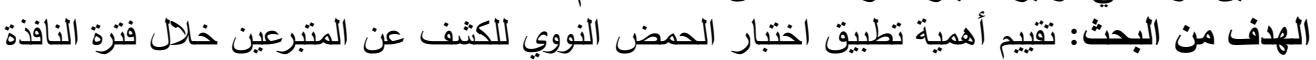

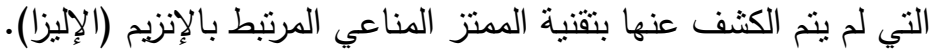

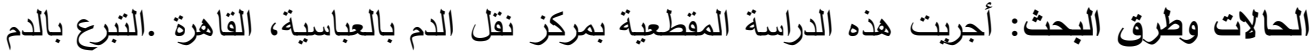

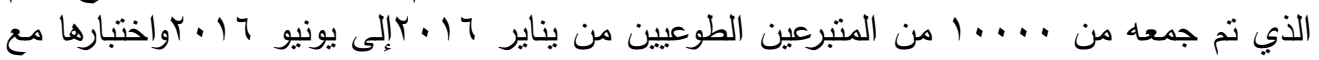
فحوصات الحمض النووى والإليزا لكل من فيروس التهائ التهاب الكبد الوبائي (سي) وفيروس التهاب التئ الكبد الوبائى (ب) وفيروس نقص المناعة البشرية. 


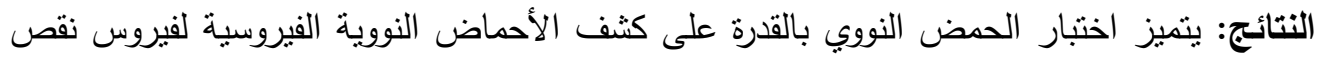

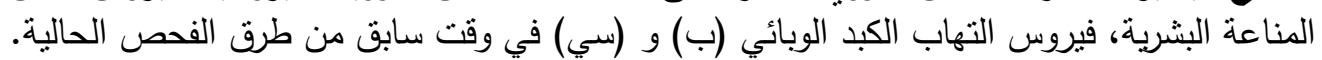

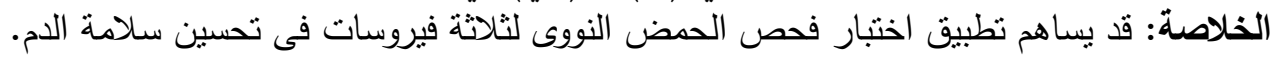

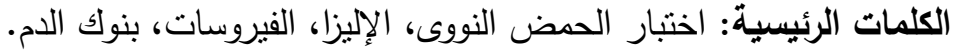

